Article

\title{
Insecticidal Activity and Synergistic Combinations of Ten Different Bt Toxins against Mythimna separata (Walker)
}

\author{
Jing Yang ${ }^{1}$, Yudong Quan ${ }^{2}$, Prabu Sivaprasath ${ }^{1}$, Muhammad Zeeshan Shabbir ${ }^{1}$, \\ Zhenying Wang ${ }^{1}$, Juan Ferré ${ }^{2}(-)$ and Kanglai He ${ }^{1, *(1)}$ \\ 1 State Key Laboratory for Biology of Plant Diseases and Insect Pests, Institute of Plant Protection, \\ Chinese Academy of Agricultural Sciences, No. 2, West Yuanmingyuan Road, Beijing 100193, China; \\ cutejingyang@163.com (J.Y.); sivaprasathibt@gmail.com (P.S.); shann2347@yahoo.com (M.Z.S.); \\ zywang@ippcaas.cn (Z.W.) \\ 2 ERI de Biotecnología y Biomedicina (BIOTECMED), Department of Genetics, Universitat de València, \\ 46100 Burjassot, Spain; yudongquan@126.com (Y.Q.); juan.ferre@uv.es (J.F.) \\ * Correspondence: klhe@ippcaas.cn
}

Received: 24 September 2018; Accepted: 1 November 2018; Published: 4 November 2018

\begin{abstract}
The oriental armyworm (OAW), Mythimna separata (Walker), is a destructive pest of agricultural crops in Asia and Australia. Commercialized Bt crops have performed very well against their target pests; however, very few studies have been done on the susceptibility of OAW to Bt toxins in either sprays or expressed in Bt crops. In this work, we evaluated the toxicities of Cry1Ab, Cry1Ac, Cry1Ah, Cry1Fa, Cry2Aa, Cry2Ab, Cry1Ie, Vip3Aa19, Vip3Aa16, and Vip3Ca against OAW neonate larvae, as well as the interaction between Cry and Vip toxins. The results from bioassays revealed that $\mathrm{LC}_{50}$ (lethal concentration for $50 \%$ mortality) values ranged from 1.6 to $78.6 \mu \mathrm{g} / \mathrm{g}$ (toxin/diet) for those toxins. Among them, Vip3 proteins, along with Cry1 A proteins and Cry2Aa, were the ones with the highest potency, with $\mathrm{LC}_{50}$ values ranging from 1.6 to $7.4 \mu \mathrm{g} / \mathrm{g}$. Synergism between Cry and Vip toxins was observed, being high in the combination of Vip3Aa16 with Cry1 toxins, with synergetic factors ranging from 2.2 to 9.2. The Vip3Ca toxin did not show any synergistic effect with any of the toxins tested. These results can help in designing new combinations of pyramiding genes in Bt crops, as well as in recombinant bacteria, for the control of OAW as well as for resistance management programs.
\end{abstract}

Keywords: Bacillus thuringiensis; Cry protein; Vip3 protein; oriental armyworm

Key Contribution: Combinations of Vip3Aa16 with Cry1 toxins as pyramids provide precise information on synergism and combined expressions of Bt genes.

\section{Introduction}

Bacillus thuringiensis $(\mathrm{Bt})$ is a gram-positive bacterium that produces pesticidal crystal proteins which are active against insects, nematodes and other invertebrates [1-3]. Since Hannay discovered the crystalline inclusion in sporulating cells of $\mathrm{Bt}$ [4], the crystal proteins have been studied extensively to control the lepidopteran pest $[1,5,6]$. Because of the lack of toxicity to vertebrates and most other nontarget organisms, Bt toxins are environmentally friendly, either applied as biopesticides, or in transgenic crops $[1,5,6]$. Currently, transgenic crops producing Bt toxins (Bt crops) that kill major target pests have been globally adopted and are grown in more than 70 million hectares annually since 2010, having reached over 100 million hectares in 2017 [7]. Despite the high number of Bt toxins discovered to date, only a few Bt toxins, such as Cry1Ab, Cry1Ac, Cry1F, Cry2Ab, Cry3, Cry1C, and Vip3A, 
are found in commercial Bt crops [8]. Although they show a high efficacy against some pests, each one of these toxins has its own insecticidal spectrum of toxicity and, therefore, only a few of them are appropriate to control a given pest [9-14]. The evolution of insect resistance is the primary threat to the continuous success of Bt crops $[15,16]$. To deal with the above two issues, strategies of stacking (combining toxins that have different insect targets) and/or pyramiding (combining toxins that have the same insect target) two or more insecticidal traits in Bt plants have been deployed, with excellent results [7]. These strategies have been shown to be very effective in achieving a broader spectrum for insect control and combating resistance [17-23]. Therefore, the characterization of which set of Bt toxins is useful in the control of a given pest is of paramount importance to predict the efficacy of Bt crops on an insect pest that has not been tested previously, and even to predict the chances of developing resistance based on previous information on cross-resistance episodes in other related species.

Both Cry and Vip3 toxins follow similar steps in their mode of action. They are synthesized as protoxins, which must be cleaved by midgut proteases to be converted into active toxins after intake by the larvae [24,25]. Activated toxins insert into the epithelial cell membrane via binding to the specific brush border receptors and elicit the formation of pores, which eventually lead to the destruction of midgut epithelial cells [26-31]. These events ultimately lead to the death of larvae by septicemia [32,33]. Despite Cry and Vip3 toxins following similar steps in the mode of action, they differ in that they do not compete for binding sites [34-38]. A combination of Vip3Aa/Cry1Ac in cotton, Vip3Aa/Cry1Ab in corn, Vip3Aa/Cry1Ac/Cry1Fa in cotton, and Vip3Aa/Cry1Ab/Cry1Fa in corn have been applied for combating resistance to the first-generation Bt cotton and corn that express Cry1Ac and Cry1Ab toxins, respectively $[17,19,20,39]$. The distinct mode of action between Cry and Vip3 proteins makes them good candidates to be combined in Bt crops to delay resistance evolution and broaden the insecticidal spectrum of the crop.

The oriental armyworm (OAW), Mythimna separata (Walker), (Lepidoptera: Noctuidae), is a well-known long-distance migratory and major agricultural pest in Asia and Australia [40-47]. Practically, control of OAW relies on chemical insecticide spray [48,49]. The adoption of Bt maize would provide new and alternative tools for limiting the damage caused by this pest. A laboratory study showed that Mythimna unipuncta could evolve resistance to Cry1 Ab [50]. In addition, the fall armyworm (FAW), Spodoptera frugiperda (another species of the same family and a long-distance migratory moth in America), which also can feed on maize [51], has been reported to have developed resistance to Cry1Fa in Bt maize [52-54]. Therefore, research on the efficacy and interaction effects of Bt toxins on OAW are urgent and needed in ecological safety, as well as in building a biological control method for this pest.

In this work, we evaluated the efficacy of individual Cry (Cry1Ab, Cry1Ac, Cry1Ah, Cry1Fa, Cry1Ie, Cry2Aa, and Cry2Ab) and Vip3 proteins (Vip3Aa19, Vip3A16, and Vip3Ca), with an interest in maize crop protection. In addition, we studied the possible synergistic effects of combinations of Cry and Vip3 proteins.

\section{Results}

\subsection{Susceptibility of Mythimna separata to Bt Toxins}

The toxicities of different Bt toxins against OAW varied considerably (Table 1). The LC 50 values ranged from 1.6 to $78.6 \mu \mathrm{g} / \mathrm{g}$. Vip3Aa19 was the toxin with the lowest $\mathrm{LC}_{50}$ value $(1.6 \mu \mathrm{g} / \mathrm{g})$, though not significantly different from Vip3Ca and Cry1Ac. However, considering the $\mathrm{LC}_{50}$ and LC 95 values together, Vip3Aa19 and Vip3Ca were the most potent toxins, followed by Cry1Ab, Cry1Ac, Cry2Aa, and Vip3Aa16. The rest of the toxins tested (Cry1Ah, Cry1Fa, Cry1Ie, and Cry2Ab) had significantly less potency, either because of having high $\mathrm{LC}_{50}$ values or by having a low regression slope. Cry1Ie was significantly the less toxic protein, with an $\mathrm{LC}_{50}$ value of $78.6 \mu \mathrm{g} / \mathrm{g}$. 
Table 1. Effect of Cry and Vip3 family protoxins against Mythimna separata neonates.

\begin{tabular}{|c|c|c|c|c|c|c|}
\hline Toxin & $n$ & $\mathrm{LC}_{50}(95 \% \mathrm{FL}) \mu \mathrm{g} / \mathrm{g} *$ & $\mathrm{LC}_{95}(95 \% \mathrm{FL}) \mu \mathrm{g} / \mathrm{g} *$ & Slope \pm SE * & $x^{2}$ & $d f\left(\chi^{2}\right)$ \\
\hline Cry1Ab & 480 & $6.4(4.2,9.0) \mathrm{c}$ & $326.5(158.3,1034.2)$ a & $0.96 \pm 0.12 b c$ & 3.3 & 5 \\
\hline Cry1Ac & 480 & $3.7(2.1,5.7) \mathrm{cd}$ & $255.0(121.0,893.7)$ a & $0.89 \pm 0.12 b c$ & 1.6 & 5 \\
\hline Cry2Aa & 528 & $6.2(3.9,9.8) \mathrm{c}$ & $725.6(229.7,5792.6)$ a & $0.80 \pm 0.12 c$ & 4.2 & 6 \\
\hline Cry $2 \mathrm{Ab}$ & 768 & $22.3(15.3,32.3) b$ & $>1000$ & $0.82 \pm 0.06 c$ & 20.8 & 14 \\
\hline Cry1Fa & 672 & $14.4(5.7,24.6) \mathrm{b}$ & $>1000$ & $0.22 \pm 0.04 c$ & 12.8 & 10 \\
\hline Cry1Ie & 672 & $78.6(47.3,160.3) \mathrm{a}$ & $>1000$ & $0.86 \pm 0.11 c$ & 13.7 & 9 \\
\hline Cry1Ah & 576 & $18.7(13.1,25.9) b$ & $>1000$ & $0.26 \pm 0.03 c$ & 9.9 & 8 \\
\hline Vip3Aa16 & 528 & $7.4(2.7,19.3) \mathrm{c}$ & $351.8(74.4,939.9)$ a & $0.98 \pm 0.14 b c$ & 17.5 & 6 \\
\hline Vip3Aa19 & 384 & $1.6(0.55,3.53) \mathrm{d}$ & $35.0(17.0,148.0) \mathrm{b}$ & $1.24 \pm 0.15 b$ & 11.2 & 6 \\
\hline Vip3Ca & 480 & $3.4(2.5,4.6) \mathrm{cd}$ & $27.1(17.4,54.9) \mathrm{b}$ & $1.83 \pm 0.19 \mathrm{a}$ & 5.2 & 5 \\
\hline
\end{tabular}

$n$, Number of larvae tested. 95\%FL, 95\% fiducial limits. *, Values followed by the same lowercase letter in the same column indicate no significant difference at $p \geq 0.05$. SE, Standard error.

\subsection{Effect of Bt Toxins Combinations against Mythimna separata}

In the search for possible synergistic interactions between Cry and Vip3 toxins, different toxin combinations were tested against the OAW neonates and results are shown in Table 2. There were four combinations showing a statistically significant interaction, all of them with Vip3Aa16 (marked with an asterisk in Table 2). For these synergistic interactions, the synergistic factor (SF) ranged from 2.2 to 9.2. No significant antagonistic effects were found.

Table 2. Susceptibility of Mythimna separata neonate larvae to combinations of Cry and Vip protoxins.

\begin{tabular}{|c|c|c|c|c|c|c|c|c|c|}
\hline Toxins & Ratio & $n$ & Slope $\pm S E$ & \multicolumn{2}{|c|}{$\mathrm{LC}_{50}(95 \% \mathrm{FL}) \mu \mathrm{g} / \mathrm{g}$} & $x^{2}$ & $d f\left(\chi^{2}\right)$ & $S F$ & $p$ \\
\hline Cry1Ab/Vip3Aa16 & $0.71: 0.29$ & 480 & $0.9 \pm 0.1$ & $3.1(1.8,4.5)$ & $6.6(3.6,10.7)$ & 2.8 & 5 & 2.2 & 0.03 \\
\hline Cry1Fa/Vip3Aa16 & $0.71: 0.29$ & 480 & $1.0 \pm 0.1$ & $1.8(0.3,3.9)$ & $11.3(4.3,22.8)$ & 9.1 & 5 & 6.3 & 0.01 \\
\hline Cry1Fa/Vip3Ca & 0.71:0.29 & 480 & $1.2 \pm 0.1$ & $11.7(5.7,21.8)$ & $7.5(4.1,10.9)$ & 11.3 & 5 & 0.6 & 0.29 \\
\hline Cry1Ie/Vip3Aa16 & $0.67: 0.33$ & 480 & $0.6 \pm 0.1$ & $2.0(0.57,3.9)$ & $18.6(7.2,46.7)$ & 1.3 & 5 & 9.2 & $<0.01$ \\
\hline Cry1Ah/Vip3Aa16 & 0.68:0.32 & 480 & $1.5 \pm 0.1$ & $5.12(3.4,7.1)$ & $12.6(5.9,23.4)$ & 1.7 & 5 & 2.5 & 0.02 \\
\hline Cry1Ah/Vip3Ca & 0.68:0.32 & 480 & $1.6 \pm 0.2$ & $8.12(5.7,10.7)$ & $7.8(5.5,10.4)$ & 0.9 & 4 & 1.0 & 0.84 \\
\hline Cry2Aa/Vip3Ca & $0.50: 0.50$ & 480 & $1.4 \pm 0.2$ & $4.07(2.4,6.2)$ & $4.4(3.0,6.2)$ & 7.8 & 5 & 1.1 & 0.78 \\
\hline
\end{tabular}

$n$, Number of larvae tested. SE, Standard error. $95 \%$ FL, 95\% fiducial limits. SF, Calculated as the expected $\mathrm{LC}_{50}$ divided by the observed $\mathrm{LC}_{50}$. $p$, Probability value based on U-test.

\subsection{Determination of the Mortality Rate}

The interaction of some combination of toxins was tested by the mortality rate at a fixed toxin concentration instead of the $\mathrm{LC}_{50}$ values. Of the four combinations tested, only the Cry2Aa/Vip3Ca combination showed a significant result (synergism), with an observed mortality of $69.8 \%$ vs. the expected $50 \%$ (Table 3 ).

Table 3. Mortality of Mythimna separata neonate larvae to combinations of Cry and Vip protoxins.

\begin{tabular}{|c|c|c|c|c|c|c|}
\hline \multirow{2}{*}{ Toxins } & \multirow{2}{*}{ Proportion } & \multirow{2}{*}{$\begin{array}{c}\text { Concentration } \\
(\mu \mathrm{g} / \mathrm{g})\end{array}$} & \multirow{2}{*}{$n$} & \multicolumn{2}{|c|}{ Mortality \pm SE (\%) } & \multirow{2}{*}{$p$} \\
\hline & & & & Observed & Expected & \\
\hline Cry1Ac/Vip3Aa16 & $0.56 / 0.44$ & 2.5 & 144 & $55.6 \pm 0.9$ & 50 & 0.69 \\
\hline Cry1Ac/Vip3Ca & $0.56 / 0.44$ & 1.8 & 144 & $48.3 \pm 0.2$ & 50 & 0.83 \\
\hline Cry2Aa/Vip3Aa16 & $0.50 / 0.50$ & 3.4 & 144 & $57.8 \pm 0.1$ & 50 & 0.35 \\
\hline Cry2Aa/Vip3Ca & $0.50 / 0.50$ & 2.2 & 144 & $69.8 \pm 0.3$ & 50 & 0.02 \\
\hline
\end{tabular}

$n$, Number of larvae tested. SE, Standard error. $p$, Probability value based on $\chi^{2}$-test. 


\section{Discussion}

It is known that insects have varying degrees of susceptibility to different $\mathrm{Bt}$ toxins, and the assessment is necessary for defining susceptibility before the implementation of commercial cultivation of Bt crops. In this study, the toxicity $\left(\mathrm{LC}_{50}\right)$ and synergistic effects of Cry and Vip3 toxins were assessed against OAW. The $\mathrm{LC}_{50}$ values obtained for OAW ranged from 1.6 to $78.6 \mu \mathrm{g} / \mathrm{g}$ for Cry and Vip toxins (Table 1). In previous reports, FAW and Ostrinia nubilalis showed higher susceptibility to Cry1Fa [54], which is even more effective than Cry1 Ab and Cry1Ac against Helicoverpa armigera [55] or Plutella xylostella [56]. Co-expressing Cry1F with Cry1Ac in cotton, and Cry1Ab in maize, can broaden the number of targets species of Bt cotton and Bt maize [39,57]. However, in this study, Cry1Fa was less efficient than Cry1Ac and Cry1Ab. This indicates differences in susceptibility to those toxins between OAW and FAW. This suggests that pyramiding Cry1F and Cry1 $\mathrm{Ab}$ in maize may not increase the efficacy against OAW control.

The $\mathrm{LC}_{50}$ and $\mathrm{LC}_{95}$ values of Vip3Aa19 and Vip3Ca did not show any significant difference. However, the slope showed a significant difference (Table 1), thus indicating that the toxicity of Vip3Ca was greater than that of Vip3Aa19. Although the value of Vip3Ca was not significantly different from those of Cry1 Ab, Cry1 Ac, and Cry2Aa at the $\mathrm{LC}_{50}$ level, it was significantly more active at the level of $\mathrm{LC}_{95}$. Vip3Ca showed remarkable efficacy against the OAW, according to both the $\mathrm{LC}_{50}$ and $\mathrm{LC}_{95}$ values, which clearly indicates that Vip3Ca could be recommended in controlling the OAW. Similarly, high slope values of Vip3A proteins were also reported in Heliothis virescens, which can be interpreted as that the activity of Vip3A proteins need a particular threshold concentration to be toxic in the insect midgut [58]. In a recent study, it was reported that Vip3Ca was as effective as Cry1 Ab against Ostrinia furnacalis, but Vip3Aa was less toxic [59]. In addition, Vip3Ca was also found to overcome resistance to Cry1 Ab in Cry1Ab-resistant O. furnacalis, indicating that Cry1 Ab and Vip3Ca may have different binding sites. This suggests that co-expressing Cry1 Ab and Vip3Ca may be a useful component in $\mathrm{OAW}$ and $O$. furnacalis pest management programs, as well as pest resistance management programs.

The interaction effect between proteins is an important issue in the selection of toxins to use in pest control and insect resistance management. A number of investigations have confirmed that synergism and antagonism may occur between Vip3 and Cry proteins [57-60]. Bergamasco et al. reported the species specificity effect of protein interaction between Cry1Ia and Vip3Aa [61-63]. A synergistic effect was found in FAW, Spodoptera albula, and Spodoptera cosmioides, but an antagonistic effect was found in Spodoptera eridania. In the present study, the highest synergistic effect was observed in the combination of Cry1Ie and Vip3Aa16. Cry1Ie is highly toxic to O. furnacalis [64] and effective in preventing the development of resistance in $H$. armigera targeted by Bt maize [65]. This suggests the potential use of combination of Cry1Ie and Vip3Aa16 in maize for a broader target species control and favoring the pest resistance management.

Cry1F expressing maize TC1507 is toxic to O. nubilalis [66], a relative species to O. furnacalis. Cry1F expressing maize has the potential to control $O$. furnacalis, as evidenced from results from both laboratory studies with pure protein [67] and field trials with TC1507 maize (unpublished data). In the present study, we found Cry1Fa and Vip3Aa16 interacted synergistically, with an SF of 6.3. This indicates that a pyramided maize plant expressing Cry1Fa and Vip3Aa16 would be a new strategy in an overall pest management program for both O. furnacalis and OAW. Meanwhile, synergistic effects were also observed in the combinations of Vip3Aa16 with either Cry1Ab (2.2-fold) or Cry1Ah (2.5-fold), although they were relatively low. Interestingly, we did not find any synergistic effect in the combinations of Vip3Ca with Cry1 type toxins (Tables 2 and 3), although previous studies suggested that the mode of action of Vip3Aa was similar to that of Vip3Ca [31,68,69]; the difference in synergistic properties may unravel differences in their mode of action at the biochemical level.

\section{Conclusions}

This study demonstrated the toxicity of seven Cry and three Vip3 protoxins to OAW. Our results reveal that, among the Bt toxins tested, Vip3Aa19 and Vip3Ca have the highest toxicity, followed by 
Cry1Ab, Cry1Ac, Cry2Aa, and Vip3Aa16, whereas Cry1Fa, Cry1Ah, Cry2Ab, and Cry1le possess the lowest larvicidal activity. Combinations of Vip3Aa16 with Cry1 toxins as pyramids showed a significant synergistic activity, while combinations of Vip3Ca with Cry1 toxins did not show any synergism. The results obtained provide precise information for projecting new combinations of Bt genes in transgenic crops for a broader target spectrum and a reliable component of pest resistance management programs.

\section{Materials and Methods}

\subsection{Insect Strains}

Eggs of OAW were obtained from Keyun Biology Company. The eggs were transferred to Zip-lock bags (\#10) and reared under laboratory conditions $\left(28 \pm 1{ }^{\circ} \mathrm{C}, \mathrm{L}: \mathrm{D}=16: 8 \mathrm{~h}, \mathrm{RH}=70 \% \sim 80 \%\right)$. Neonates were used for diet bioassay within $6 \mathrm{~h}$ after hatching.

\subsection{Diet Formulation}

Artificial diet was formulated according to Wang and Zheng [70] with slight modifications. Ingredients: $250 \mathrm{~g}$ of powdered rat feed, $300 \mathrm{~g}$ of powdered corn leaf, soybean flour $40 \mathrm{~g}$, corn flour $50 \mathrm{~g}$, wheat germ $30 \mathrm{~g}$, casein $20 \mathrm{~g}$, yeast $40 \mathrm{~g}$, glucose $20 \mathrm{~g}$, fructose $20 \mathrm{~g}$, sugar $30 \mathrm{~g}$, Weber's salt mixture $10 \mathrm{~g}$, ascorbic acid $6 \mathrm{~g}$, cholesterol $2 \mathrm{~g}$, mixed vitamins $1 \mathrm{~g}$, sorbic acid $6 \mathrm{~g}$, erythromycin $1.2 \mathrm{~g}$, and thiabendazole $2 \mathrm{~g}$. These powders were mixed together, vacuum packed, and stored at $4{ }^{\circ} \mathrm{C}$ until use.

\subsection{Bt Toxins}

Trypsin-activated Cry1Ab, Cry1Ac, Cry2Aa, Cry2Ab, and Cry1Fa toxins were purchased from Envirologix (Portland, OR, USA). Cry1Ie and Cry1Ah are chromatographically purified recombinant proteins expressed in Escherichia coli and Bacillus thuringiensis (Biot $1 \mathrm{Ah}$ ), which were provided by the Chinese Academy of Agricultural Sciences, Biotech group. Vip3Aa16 and Vip3Ca were provided by the Department of Genetics, University of Valencia (Valencia, Spain). Vip3Aa19 was provided by the Da Bei Nong Group.

\subsection{Bioassays}

\subsubsection{Bt Toxin Bioassay}

Ten toxins were used to check their toxicity against OAW neonates. Initially, the Bt toxins stock solutions $(1 \mathrm{mg} / \mathrm{mL})$ were prepared by dissolving the toxins in sodium carbonate buffer $(50 \mathrm{mM}$, $\mathrm{pH}=10)$ separately in their respective vials. In a $50 \mathrm{~mL}$ beaker, the protoxins were mixed thoroughly with the diet $(3.5 \mathrm{~g})$ and distilled water $(6.5 \mathrm{~mL})$. The Bt toxicity screening was performed by increasing the concentration gradually according to Shabbir et al., 2018 [71]. This mixture was divided equally into the cells of a 48-well plate. One OAW neonate was placed on the surface of the diet in each well, using a fine brush. These plates were sealed with sealing film and a small hole was punctured on each well and these plates were placed in the rearing room $\left(28 \pm 1{ }^{\circ} \mathrm{C}, \mathrm{L}: \mathrm{D}=16: 8 \mathrm{~h}, \mathrm{RH}=70 \% \sim 80 \%\right)$. The survival rate and larval weight were recorded after 7 days. Larva weighed $<0.2 \mathrm{mg}$ and was beyond second instar, so it was considered dead.

\subsubsection{Assessment of Synergism between Bt Toxins}

The synergetic effect between Bt toxins was assessed using combinations of the Cry and Vip3 families. In choosing the toxin ratios, the Cry $1 \mathrm{Ab}$ is exemplified in order to bring the expected $\mathrm{LC}_{50}$ values of the toxin mixture to an appropriate range. A ratio of $0.7 / 0.3$, or close to it, was chosen for ease of comparison and calculation. The diet bioassays for different combinations of Bt toxins were 
carried out with the same method as the one mentioned above for single toxins. Three replications were performed for each combination.

\subsection{Statistical Analysis}

PoloPlus (v 1.0, LeOra Software, Parma, MO, USA) was employed to estimate the $50 \%$ lethal concentration ( $\left.\mathrm{LC}_{50}\right)$ with $95 \%$ fiducial limits (FL) and the slope for bioassays by probit analysis. Tests for expected and observed mortalities were evaluated using the method described by Tabashnik [68]. Differences between observed and expected $\mathrm{LC}_{50}$ values were analyzed by the U-test, that is, the $\mathrm{LC}_{50}$ ratio test [72]. The difference between the observed and expected mortalities was analyzed by conducting a $\chi^{2}$-test. Both U-test and $\chi^{2}$-test were run through the SAS 9.4 software (North Carolina State University, Raleigh, NC, USA).

Author Contributions: K.H., Y.Q. and J.Y. conceived and designed the experiments; J.Y. and Y.Q. performed the experiments; Z.W. contributed reagents, material; J.Y. and Y.Q. analyzed the data; K.H., J.Y., M.Z.S., P.S., J.F. and K.H. wrote the paper.

Funding: This research was funded by Genetically Modified Organisms Breeding Major Projects (2016ZX08003-001).

Conflicts of Interest: The authors declare no conflict of interest.

\section{References}

1. Palma, L.; Muñoz, D.; Berry, C.; Murillo, J.; Caballero, P. Bacillus thuringiensis toxins: An overview of their Biocidal activity. Toxins 2014, 6, 3296-3325. [CrossRef] [PubMed]

2. Wei, J.Z.; Hale, K.; Carta, L.; Platzer, E.; Wong, C.; Fang, S.C.; Aroian, R.V. Bacillus thuringiensis crystal proteins that target nematodes. Proc. Natl. Acad. Sci. USA 2003, 100, 2760-2765. [CrossRef] [PubMed]

3. Iatsenko, I.; Nikolov, A.; Sommer, R.J. Identification of distinct Bacillus thuringiensis 4A4 nematicidal factors using the model nematodes Pristionchus pacificus and Caenorhabditis elegans. Toxins 2014, 6, 2050-2063. [CrossRef] [PubMed]

4. Hannay, C.L. Crystalline inclusions in aerobic sporeforming Bacteria. Nature 1953, 172, 1004. [CrossRef] [PubMed]

5. Frankenhuyzen, K.V. Cross-order and cross-phylum activity of Bacillus thuringiensis pesticidal proteins. J. Invertebr. Pathol. 2013, 114, 76-85. [CrossRef] [PubMed]

6. Schnepf, E.; Crickmore, N.; Rie, J.V.; Lereclus, D.; Baum, J.; Feitelson, J. Bacillus thuringiensis and its pesticidal crystal proteins. Microbiol. Mol. Biol. 1998, 62, 775-806.

7. James, C. Global Status of Commercialized Biotech/GM Crops in 2017: Biotech Crop Adoption Surges as Economic Benefits Accumulate in 22 Years; ISAAA Briefs 53; ISAAA: Manila, Philippines, 2017.

8. ISAAA GM Approval Database. Available online: http://www.isaaa.org/gmapprovaldatabase/default.asp (accessed on 20 September 2018).

9. Hernández-Martínez, P.; Hernández-Rodríguez, C.S.; Rie, J.V.; Escriche, B.; Ferré, J. Insecticidal activity of Vip3Aa, Vip3Ad, Vip3Ae, and Vip3Af from Bacillus thuringiensis against lepidopteran corn pests. J. Invertebr. Pathol. 2013, 113, 78-81. [CrossRef] [PubMed]

10. Ruiz de Escudero, I.; Banyuls, N.; Bel, Y.; Maeztu, M.; Escriche, B.; Muñoz, D.; Caballero, P.; Ferré, J. A screening of five Bacillus thuringiensis Vip3A proteins for their activity against lepidopteran pests. J. Invertebr. Pathol. 2014, 117, 51-55. [CrossRef] [PubMed]

11. Walters, F.S.; Stacy, C.M.; Lee, M.K.; Palekar, N.; Chen, J.S. An engineered chymotrypsin/cathepsin $\mathrm{G}$ site in domain I renders Bacillus thuringiensis Cry3A active against Western corn rootworm larvae. Appl. Environ. Microbiol. 2008, 74, 367-374. [CrossRef] [PubMed]

12. Walters, F.S.; de Fontes, C.M.; Hart, H.; Warren, G.W.; Chen, J.S. Lepidopteran-active variable-region sequence imparts coleopteran activity in eCry3.1Ab, an engineered Bacillus thuringiensis hybrid insecticidal protein. Appl. Environ. Microbiol. 2010, 76, 3082-3088. [CrossRef] [PubMed]

13. Chakroun, M.; Banyuls, N.; Bel, Y.; Escriche, B.; Ferré, J. Bacterial vegetative insecticidal proteins (Vip) from entomopathogenic bacteria. Microbiol. Mol. Biol. Rev. 2016, 80, 329-350. [CrossRef] [PubMed] 
14. Estruch, J.J.; Warren, G.W.; Mullins, M.A.; Nye, G.J.; Craig, J.A.; Koziel, M.G. Vip3A, A novel Bacillus thuringiensis vegetative insecticidal protein with a wide spectrum of activities against lepidopteran insects. Proc. Natl. Acad. Sci. USA 1996, 93, 5389-5394. [CrossRef] [PubMed]

15. Tabashnik, B.E. Evolution of resistance to Bacillus thuringiensis. Annu. Rev. Entomol. 1994, 39, 47-49. [CrossRef]

16. Ferré, J.; Rie, J.V. Biochemistry and genetics of insect resistance to Bacillus thuringiensis. Annu. Rev. Entomol. 2002, 47, 501-533. [CrossRef] [PubMed]

17. Adamczyk, J.J.; Mahaffey, J.S. Efficacy of Vip3a and Cry1Ab transgenic traits in cotton against various lepidopteran pests. Fla. Entomol. 2008, 91, 570-575.

18. Roush, R.T. Two-toxin strategies for management of insecticidal transgenic crops: Can pyramiding succeed where pesticide mixtures have not? Philos. Trans. R. Soc. Lond. Ser. B Biol. Sci. 1998, 353, 1777-1786. [CrossRef]

19. Zhao, J.Z.; Cao, J.; Li, Y.X.; Collins, H.L.; Roush, R.T.; Earle, E.D.; Shelton, A.M. Transgenic plants expressing two Bacillus thuringiensis toxins delay insect resistance evolution. Nat. Biotechnol. 2003, 21, 1493-1497. [CrossRef] [PubMed]

20. Carrière, Y.; Crickmore, N.; Tabashnik, B.E. Optimizing pyramided transgenic Bt crops for sustainable pest management. Nat. Biotechnol. 2015, 33, 161-168. [CrossRef] [PubMed]

21. Carrière, Y.; Fabrick, J.A.; Tabashnik, B.E. Can pyramids and seed mixtures delay resistance to Bt crops? Trends Biotechnol. 2016, 34, 291-302. [CrossRef] [PubMed]

22. Zhao, J.Z.; Cao, J.; Collins, H.L.; Bates, S.L.; Roush, R.T.; Earle, E.D. Concurrent use of transgenic plants expressing a single and two Bacillus thuringiensis genes speeds insect adaptation to pyramided plants. Proc. Natl. Acad. Sci. USA 2005, 102, 8426-8430. [CrossRef] [PubMed]

23. Tabashnik, B.E.; Unnithan, G.C.; Masson, L.; Crowder, D.W.; Li, X.C.; Carrière, Y. Asymmetrical cross-resistance between Bacillus thuringiensis toxins Cry1Ac and Cry2Ab in pink bollworm. Proc. Natl. Acad. Sci. USA 2009, 106, 11889-11894. [CrossRef] [PubMed]

24. Andrews, R.E.; Bibilos, M.M.; Bulla, L.A. Protease activation of the entomocidal protoxin of Bacillus thuringiensis subsp. kurstaki. Appl. Environ. Microbiol. 1985, 50, 737-742. [PubMed]

25. Caccia, S.; Chakroun, M.; Vinokurov, K.; Ferré, J. Proteolytic processing of Bacillus thuringiensis Vip3A proteins by two Spodoptera species. J. Invertebr. Pathol. 2014, 67, 76-84. [CrossRef] [PubMed]

26. Knowles, B.H. Mechanism of action of Bacillus thuringiensis insecticidal $\delta$-endotoxins. Adv. Insect Physiol. 1994, 24, 275-308.

27. Bravo, A.; Gómez, I.; Conde, J.; Munoz-Garay, C.; Sanchez, J.; Miranda, R.; Zhuang, M.; Gill, S.S.; Soberón, M. Oligomerization triggers binding of a Bacillus thuringiensis Cry1Ab pore-forming toxin to aminopeptidase $\mathrm{N}$ receptor leading to insertion into membrane microdomains. Biochim. Biophys. Acta 2004, 1667, $38-46$. [CrossRef] [PubMed]

28. Bravo, A.; Gill, S.S.; Soberón, M. Mode of action of Bacillus thuringiensis Cry and Cyt toxins and their potential for insect control. Toxicon 2007, 49, 423-435. [CrossRef] [PubMed]

29. Gómez, I.; Pardo-López, L.; Muñoz-Garay, C.; Fernández, L.E.; Pérez, C.; Sénchez, J.; Soberón, M.; Bravo, A. Role of receptor interaction in the mode of action of insecticidal Cry and Cyt toxins produced by Bacillus thuringiensis. Peptides 2007, 28, 169-173. [CrossRef] [PubMed]

30. Pardo-López, L.; Soberón, M.; Bravo, A. Bacillus thuringiensis insecticidal three-domain Cry toxins: Mode of action, insect resistance and consequences for crop protection. FEMS Microbiol. Rev. 2013, 37, 3-22. [CrossRef] [PubMed]

31. Gomis-Cebolla, J.; Ruiz de Escudero, I.; Vera-Velasco, N.M.; Hernández-Martínez, P.; Hernández-Rodríguez, C.S.; Ceballos, T.; Palma, L.; Escriche, B.; Caballero, P.; Ferré, J. Insecticidal spectrum and mode of action of the Bacillus thuringiensis Vip3Ca insecticidal protein. J. Invertebr. Pathol. 2017, 142, 60-67. [CrossRef] [PubMed]

32. Yu, C.G.; Mullins, M.A.; Warren, G.W.; Koziel, M.G.; Estruch, J.J. The Bacillus thuringiensis vegetative insecticidal protein Vip3A lyses midgut epithelium cells of susceptible insects. Appl. Environ. Microbiol. 1997, 63, 532-536. [PubMed]

33. Caccia, S.; Di Lelio, I.; La Storia, A.; Marinelli, A.; Varricchio, P.; Franzetti, E.; Banyuls, N.; Tettamanti, G.; Casartelli, M.; Giordana, B.; et al. Midgut microbiota and host immunocompetence underlie Bacillus thuringiensis killing mechanism. Proc. Natl. Acad. Sci. USA 2016, 113, 9486-9491. [CrossRef] [PubMed] 
34. Lee, K.L.; Miles, P.; Chen, J.S. Brush border membrane binding properties of Bacillus thuringiensis Vip3A toxin to Heliothis virescens and Helicoverpa zea midguts. Biochem. Biophy. Res. Commun. 2006, 339, 1043-1047. [CrossRef] [PubMed]

35. Sena, J.A.D.; Hernández-Rodríguez, C.S.; Ferré, J. Interaction of Bacillus thuringiensis Cry1 and Vip3Aa proteins with Spodoptera frugiperda midgut binding sites. Appl. Environ. Microbiol. 2009, 75, 2236-2237. [CrossRef] [PubMed]

36. Abdelkefi-Mesrati, L.; Rouis, S.; Sellami, S.; Jaoua, S. Prays oleae midgut putative receptor of Bacillus thuringiensis vegetative insecticidal protein Vip3LB differs from that of Cry1Ac toxin. Mol. Biotechnol. 2009, 43, 15-19. [CrossRef] [PubMed]

37. Chakroun, M.; Ferré, J. In vivo and in vitro binding of Vip3Aa to Spodoptera frugiperda midgut and characterization of binding sites by 125I radiolabeling. Appl. Environ. Microbiol. 2014, 80, 6258-6265. [CrossRef] [PubMed]

38. Gouffon, C.; van Vliet, A.; van Rie, J.; Jansens, S.; Jurat-Fuentes, J.L. Binding sites for Bacillus thuringiensis Cry2Ae toxin on heliothine brush border membrane vesicles are not shared with Cry1A, Cry1F, or Vip3A toxin. Appl. Environ. Microbiol. 2011, 77, 3182-3188. [CrossRef] [PubMed]

39. Chen, W.B.; Lu, G.Q.; Cheng, H.M.; Liu, C.X.; Xiao, Y.X.; Xu, C.; Shen, Z.C.; Wu, K.M. Transgenic cotton coexpressing Vip3A and Cry1Ac has a broad insecticidal spectrum against lepidopteran pests. J. Invertebr. Pathol. 2017, 149, 59-65. [CrossRef] [PubMed]

40. Burgess, E.P.J. Population dynamics of Mythimna separata and its parasitoid, Cotesia ruficrus, on maize in New Zealand. N. Z. J. Agric. Res. 1987, 30, 203-208. [CrossRef]

41. Drake, V.; Gatehouse, A. (Eds.) Insect migration in relation to weather and climates. In Insect Migration: Tracking Resources through Space and Time; Cambridge University Press: London, UK, 1995; pp. 93-150.

42. Sharma, H.C.; Sullivan, D.J.; Bhatnagar, V.S. Population dynamics and natural mortality factors of the oriental armyworm, Mythimna separata (Lepidoptera: Noctuidae), in South Central India. Crop. Prot. 2002, 21, 721-732. [CrossRef]

43. Chang, X.Q.; Shu, Z.; Liang, L. Insight into the ultrastructure of antennal sensilla of Mythimna separata (Lepidoptera: Noctuidae). J. Insect Sci. 2015, 15, 124. [CrossRef] [PubMed]

44. EPPO Global Database. Available online: https://gd.eppo.int/taxon/PSEDSE/distribution (accessed on 20 August 2018).

45. Kouassi, L.N.; Tsuda, K.; Goto, C. Biological activity and identification of nucleopolyhedroviruses isolated from Mythimna separata and Spodoptera litura in Japan. Biol. Control 2009, 54, 537-548. [CrossRef]

46. Sharma, H.C.; Davies, J.C. The Oriental Armyworm, Mythimna separata (Wal.) Distribution, Biology and Control: A Literature Review; Center for Oversea Pest Research, ODA Miscellaneous Report 59; Center for Oversea Pest: London, UK, 1983.

47. Jiang, Y.Y.; Li, C.G.; Zen, J.; Liu, J. Population dynamics of the armyworm in China: A review of the past 60 years' research. Chin. J. Appl. Entomol. 2014, 51, 890-898.

48. Wang, J.D.; Chen, L.F.; Wang, Y.R.; Fu, H.Y.; Ali, A.; Xiao, D.; Wang, R.; Gao, S.J. Silence of ryanodine receptor gene decreases susceptibility to chlorantraniliprole in the oriental armyworm, Mythimna separata (walker). Pesticide Biochem. Physiol. 2018, 148, 34-41. [CrossRef] [PubMed]

49. Song, Y.; Wang, H.; Chen, Y.; Wang, S.; Sun, H. Cross-resistance and biochemical resistance mechanisms of emamectin benzoate resistant population of Mythimna separate. Chin. J. Pesticide Sci. 2017, 19, 18-24.

50. González-Cabrera, J.; García, M.; Hernández-Crespo, P.; Farinós, G.P.; Ortego, F.; Castañera, P. Resistance to Bt maize in Mythimna unipuncta (lepidoptera: Noctuidae) is mediated by alteration in Cry1Ab protein activation. Insect Biochem. Mol. Biol. 2013, 43, 635-643. [CrossRef] [PubMed]

51. Buntin, G.D.; Lee, R.D.; Wilson, D.M.; Mcpherson, R.M. Evaluation of yieldgard transgenic resistance for control of fall armyworm and corn earworm (Lepidoptera: Noctuidae) on corn. Fla. Entomol. 2001, 81, 37-42. [CrossRef]

52. Storer, N.P.; Babcock, J.M.; Schlenz, M.; Meade, T.; Thompson, G.D.; Bing, J.W.; Huckaba, R.M. Discovery and characterization of field resistance to Bt maize: Spodoptera frugiperda (Lepidoptera: Noctuidae) in Puerto Rico. J. Econ. Entomol. 2010, 103, 1031-1038. [CrossRef] [PubMed] 
53. Monnerat, R.; Martins, E.; Macedo, C.; Queiroz, P.; Praça, L.; Soares, C.M.; Moreira, H.; Grisi, I.; Sila, J.; Soberón, M. Evidence of field-evolved resistance of Spodoptera frugiperda to Bt corn expressing Cry1F in Brazil that is still sensitive to modified Bt toxins. PLOS ONE 2015, 10, e0119544. [CrossRef] [PubMed]

54. Omoto, C.; Bernardi, O.; Salmeron, E.; Sorgatto, R.J.; Dourado, P.M.; Crivellari, A.; Carvalho, R.A.; Willse, A.; Martinelli, S.; Head, G.P. Field-evolved resistance to Cry1Ab maize by Spodoptera frugiperda in Brazil. Pest Manag. Sci. 2016, 72, 1727-1736. [CrossRef] [PubMed]

55. Ibargutxi, M.A.; Muñoz, D.; Escudero, I.R.D.; Caballero, P. Interactions between Cry1Ac, Cry2Ab, and Cry1Fa Bacillus thuringiensis toxins in the cotton pests Helicoverpa armigera (Hübner) and Earias insulana (Boisduval). Biol. Control 2008, 47, 89-96. [CrossRef]

56. Granero, F.; Ballester, V.; Ferre, J. Bacillus thuringiensis crystal proteins Cry1Ab and Cry1Fa share a high affinity binding site in Plutella xylostella (L.). Biochem. Bioph. Res. Commun. 1996, 224, 779-783. [CrossRef] [PubMed]

57. Siebert, M.W.; Babock, J.M.; Nolting, A.; Santos, A.C.; Adamczyk, J.J.; Neese, P.A.; King, J.E.; Jenkins, J.N.; McCarty, J.; Lorenz, G.M.; et al. Efficacy of Cry1F insecticidal protein in maize and cotton for control of fall armyworm (Lepidoptera: Noctuidae). Fla. Entomol. 2008, 81, 555-565.

58. Lemes, A.R.N.; Davolos, C.C.; Legori, P.C.B.C.; Fernandes, O.A.; Ferré, J.; Lemos, M.V.F.; Desiderio, J.A. Synergism and antagonism between Bacillus thuringiensis Vip3A and Cry1 proteins in Heliothis virescens, Diatraea saccharalis and Spodoptera frugiperda. PLoS ONE 2014, 9, e107196. [CrossRef] [PubMed]

59. Gomis-Cebolla, J.; Wang, Y.; Quan, Y.; He, K.; Walsh, T.; James, B.; Downes, S.; Kain, W.; Wang, P.; Leonard, K.; et al. Analysis of cross-resistance to Vip3 proteins in eight insect colonies, from four insect species, selected for resistance to Bacillus thuringiensis insecticidal proteins. J. Invertebr. Pathol. 2018, 155, 64-70. [CrossRef] [PubMed]

60. Graser, G.; Walters, F.S.; Burns, A.; Sauve, A.; Raybould, A. A general approach to test for interaction among mixtures of insecticidal proteins which target different orders of insect pests. J. Insect Sci. 2017, 17, 1-12. [CrossRef] [PubMed]

61. Bergamasco, V.B.; Mendes, D.R.P.; Fernandes, A.O.; Desidério, J.A.; Lemos, M.V.F. Bacillus thuringiensis Cry1Ia10 and Vip3Aa protein interactions and their toxicity in Spodoptera spp. (Lepidoptera). J. Invertebr. Pathol. 2013, 112, 152-158. [CrossRef] [PubMed]

62. Iatsenko, I.; Boichenko, I.; Somme, R.J. Bacillus thuringiensis DB27 produces two novel Protoxins, Cry21Fa1 and Cry21Ha1, which act synergistically against nematodes. Appl. Environ. Microbiol. 2014, 80, 3266-3275. [CrossRef] [PubMed]

63. Wang, Z.; Fang, L.; Zhou, Z.; Pacheco, S.; Gómez, I.; Song, F.; Bravo, A. Specific binding between Bacillus thuringiensis Cry9Aa and Vip3Aa toxins synergizes their toxicity against Asiatic rice borer (Chilo suppressalis). J. Biol. Chem. 2018, 293, 11447-11458. [CrossRef] [PubMed]

64. Song, F.P.; Zhang, J.; Gu, A.X.; Wu, Y.; Han, L.L.; He, K.L.; Chen, Z.Y.; Yao, J.; Hu, Y.Q.; Li, G.X.; et al. Identification of cry1I-Type genes from Bacillus thuringiensis strains and characterization of a novel cry1I-type gene. Appl. Environ. Microbiol. 2003, 69, 5207-5211. [CrossRef] [PubMed]

65. Zhang, Y.W.; Liu, Y.J.; Ren, Y.; Liu, Y.; Liang, G.M.; Song, F.P.; Bai, S.X.; Wang, J.H.; Wang, G.Y. Overexpression of a novel Cry1Ie gene confers resistance to Cry1Ac-resistant cotton bollworm in transgenic lines of maize. Plant Cell Tissue Organ. Cult. 2013, 115, 151-158. [CrossRef]

66. Siegfried, B.D.; Spencer, T.; Crespo, A.; Pereira, E.; Marcon, P. Ten years of Bt resistance monitoring in the European corn borer: What we know, what we don't know, and what we can do better. Am. Entomol. 2006, 53, 208-214. [CrossRef]

67. Wang, Y.; Wang, Y.; Wang, Z.; Bravo, A.; Soberón, M.; He, K. Genetic basis of Cry1F-resistance in a laboratory selected Asian corn borer strain and its cross-resistance to other Bacillus thuringiensis toxins. PLoS ONE 2016, 11, e0161189. [CrossRef] [PubMed]

68. Tabashnik, B.E. Evaluation of synergism among Bacillus thuringiensis toxins. Appl. Environ. Microbiol. 1992, 58, 3343-3346. [PubMed]

69. Liao, C.; Heckel, D.G.; Akhurst, R. Toxicity of Bacillus thuringiensis insecticidal proteins for Helicoverpa armigera and Helicoverpa punctigera (Lepidoptera: Noctuidae), major pests of cotton. J. Invertebr. Pathol. 2002, 80, 55-63. [CrossRef] 
70. Wang, Y.N. Manual of Artificial Insect Diet; Shanghai Scientific and Technical Publishers: Shanghai, China, 1984; pp. 44-47.

71. Shabbir, M.Z.; Quan, Y.; Wang, Z. Characterization of the Cry1Ah resistance in Asian corn Borer and its cross-resistance to other Bacillus thuringiensis toxins. Sci. Rep. 2018, 8, 234. [CrossRef] [PubMed]

72. Wheeler, M.W.; Park, R.M.; Bailer, A.J. Comparing median lethal concentration values using confidence interval overlap or ratio tests. Environ. Toxicol. Chem. 2006, 25, 1441-1444. [CrossRef] [PubMed] 